台湾法制史と土地法研究

年 法九葉

代制九で台 後史○は台 半年な湾

かが代り法

らほ後。史

はほ半こ史

中只のと

国中ら言と

以国で葉い

外法は老

の制な我言

東史か々葉

のとう耳目

国同かに本

々義。专に

のでかるお

法あつよい

制ってうて

史た日にそ

研が本なれ

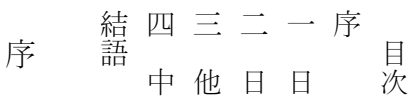

国分本本

$\stackrel{1}{\square}$

法野近に

制に代お

史お法け

にけ制る

おる史台

け土に湾

る地お法

土法け制

地研る史

法究土研

研地究

湾

法

制

史

と

土

地

法

研

究、でっほ

がこはたど

盛のつの古

に九東はい

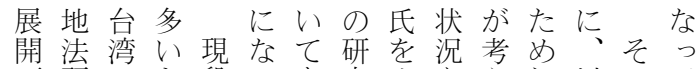
可研のと段っも究中をえわ以のて 能究法い階た、が心知られ前一き 性と制うでと台盛とるれわにつた へい史わは言湾んし機るれ比のよ のう研け台えにとた会。の尓う 探観究で湾るつな学こ目多因に 究点のは法。いっ増のもくと思 を古うな制てて中え状よのしわ 試らちい史のき国た況り国てれ 又分筆。研専た法のの多々はる

る析者々究門。制だ中くの各 もをののに的そ史がでの情国 の加目前属なしし、国報間

でえが提守法てとそ台々がの ある及のる制時はの湾に日交 るこん下文史を異頃に向本流 とだ、献研同なかおくにが そでも本は究じるらけよも盛 の、の稿、がく台るうたん 際今にはま登し台湾法にらに 近後つ現だ場て湾で制なさな 代のい段そ方日法は史っれる 日研て階れる本律主のた と

の本究土でほ まにに史泰研こそとと 
の学升例る台研奈ののの 主評台とま灣究子研研近中本 のし灣てた㕕・ロが文のので 講九法り拙治ア日最献日土は 演五律し稿時ジ本もの本地日 原、文可期乃統よ紹で法本 稿二化名台的地治く介はにに $の$ 中城湾法域時紹も台関お 訳 ○的法の律研期介し湾わけ が七日学法㗆究台さばとるる 見年本凹文革七湾机しの研台 ら因五化 ンのてば学究湾 れの素八中聯夕法いな術を法 る。翻 … 現で訳以四旦本一二革例るが梳認史 在あ法二の九 $\bar{\bigcirc}$ 石。盛る研 もる層 $\bigcirc$ 要九二東ば前ん。究 王。面○素九 $\bigcirc$ 洋後掲で状 泰こ爲九年年大藤のあ 況 升の例年司学武王る学 氏他 法のは秀泰た概 はいつはの翻、ジ・升め、観 精く政、側訳王ア宮氏 力つ大王面で泰文畑は台 的も法泰をあ升化加そ湾々

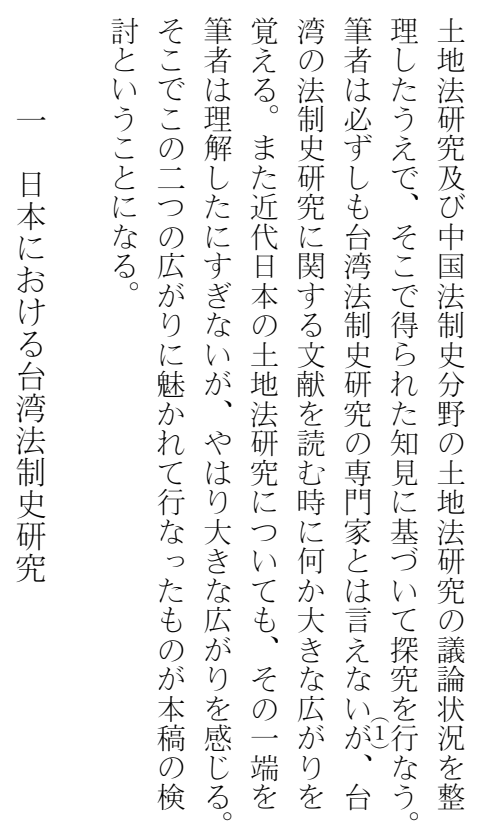

討そ筆覚湾筆理土

とこ者えの者し地

てではる法はた法

の解ま史ずえ究

と二した研しで及

なのに代に台そ中

る広す日関湾こ国

りなのる制得制 にい土文史ら史 魅が地献研れ分 か、法を究た野 乙究却而士 行りに時門に地 な大つに家基法 されい何とつ研 なとがい究 のが、きえ探議 がりそなな究論 本をの広いを状 のじ端り、なを 検るをを台う整

会日とう点法っを直までやで析所論法報中て律に

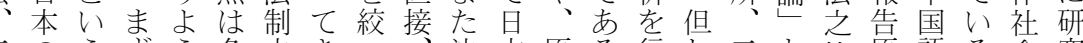
二のうずう各史きつ、法本原る行し二と比原語る會究 ○植視日な々のたた法制で文のな先 $\bigcirc$ し較稿に。史を ○民点本も関研とうや史発がでい述○て…が翻ま與進 八地か統の連究思え法研表中、たの七㙁訳た法め 年法ら治でしにわで制究さ文台い如年臺日秀さ中律 制検下は合おれ芰にれの湾とく灣本美れ文論極 は、討になういる台を含たも法の本に史帝訳てか證最

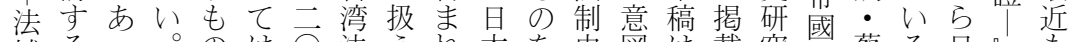
植域るっ○のは○法うれ本を史図は載究在蔡る日乎 民統もたで主制もる語翻研か今さ焦慧場文元、

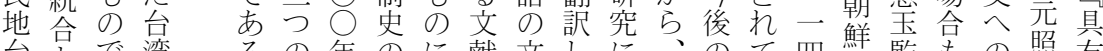
台とて湾るの年のに献文しに可て四鮮監もの照有 湾帝あのの視代研対は献た属扱研い!與修あ翻出歴

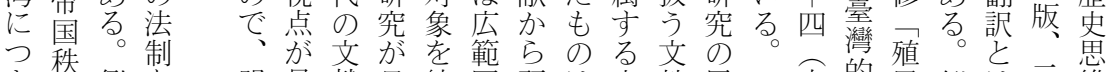
き序例を明見献日絞囲研は文献展 痤 5 他本るに究対献の開 内多のにれ目で。及状象の対可 地名浅諸分るをかこぶ況とう象能 法古野要け。通なのがをせちを性 と屋豊因 ら但守りよ、辿ず中絞に 台大美と札と盛うこりり文る対

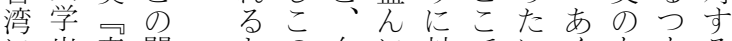
に出帝関との台に対でいくももる お版国連い視湾な象は。まのり分
中的殖例 と二思 央地地え逆 $\bigcirc$ 的 研方統ばに一法 究制治山、○学 院度法中日年 臺萹與永本 結 灣中内之語を合 史心地佑文出台 研的統氏献版灣 究討治の がし 法 


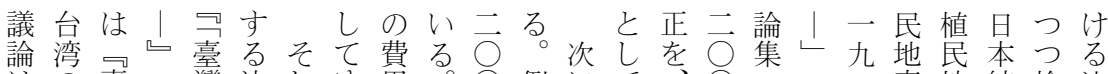

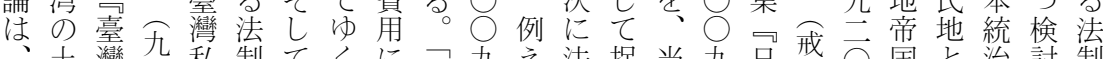
土灣九州私制てくに祭九え法捉当九日戒 $\vec{\bigcirc}$ 国 西地私州法度更も当祭年ばとえ時年本能年日し早しの 欧慣法学とにのて祀後密てのの社通代本て朝て関

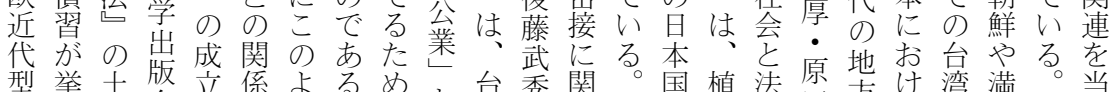
型挙土版立係よるめと台秀関。国植法圄方け湾満。当

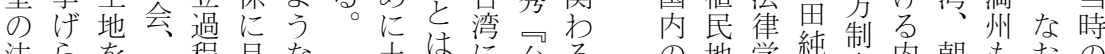
法らを一程目な至は台るの地学純制内朝もおの 観れ巡二|云台地飞見湾台社台|孝度地鮮分浅日

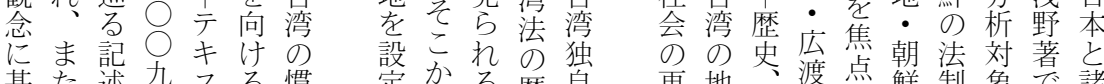
基た述九スる慣定かる歴自再地、渡点鮮制象で諸

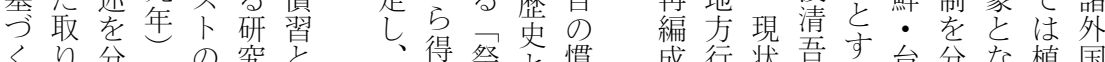
くり分かの究と、得祭と慣成行状吾す台分な植国 な上析が層が新々ら罟習に政編る湾析っ民と らげし挙位あたのれ公想によ制展渡罢統市て地の 慣らてげ学るに方業想注る度望渡民治るい法関 習れおら的。設地收塄国や辺統法山る制係 はるりれ分例けをを益を法昌㞎教日洋合の中。をを ど慣、る析えら 一取律る統育本三の比永まい視 う習そ。をばれ族祖り文研合制評先視較之たう野 捉関こ西中西よで先上化究の度論生点研佑日こに え連で著心英う継祭げ社が二の社追か究古本と入 らのはでに昭と承叔て環改悼ら|植のでれ

第る土て章典八使慣でた期認者小がそさ利者力教 音行地い・人割用習あ。にめが租わのら用にあ台こる

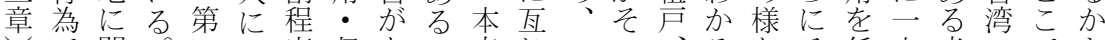
。で関。四返度收あっ来り、地の、るなそ任定者のでと す胎章却益る西の、地士元。状のせのが土土の 金る胎草却をさこ著土子基地のこ態土る租土地地問 銭契はま狆得せと序地孫租を開の㤎地と料地慣法題

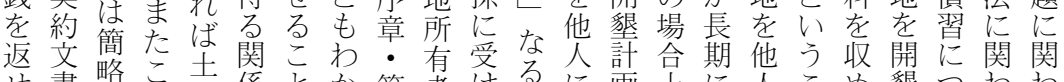
せ書略こ地係とか第者けるに画圭に人こ墾つわわ ばを化の地でとる至が継金付者地唒にとる守いるる

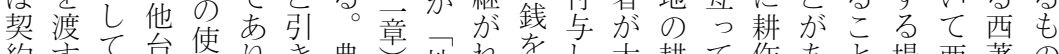
約守て台使りき曲卓地机をし大耕て作あと場西著の 文こ述蛮用、換

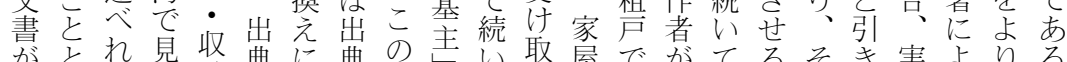

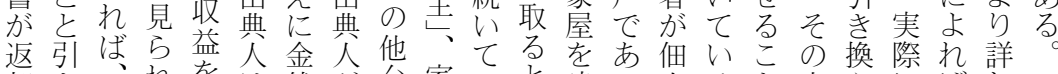

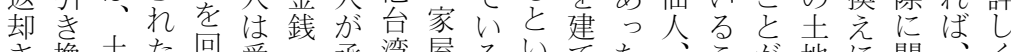

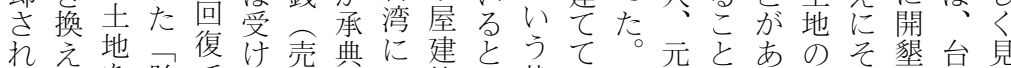
るにを胎で取却人は築い状居まのがる管の筰湾て と金も七きっ額につ者う態住た土多こ理土業へみ 言銭つもるたの当典がこが告土地かと地をのる

うを者挙つ金五該とつとやる地利っ、利の行移 受がげ西額割主と厝もはこの用たそ用管な民 西け当ら著をか地い主ありと所者こし者理っで 著取該机序承らのう吅長有がとてが・た資 
問土地なが巡ん権己人ド関読典説とと租言れ 以題地基くここ指るだをのののわれ典ま明小いた ぞ次 上との基、の摘議も中品所見る替とたさ租うに。れに 西な子主特他さ論の止で有解明えと西れ意う西无西 著つ使と殊西れがとしあ物を治る堵てが味き著何著 のた用とな家なて同たつと取期当角にい持に、はかに 内こ・屋孔でい所視とてなりの時角おるちなあ澤しよ 容と収屋債はる有守いももっ上議の語い点、るる村をれ

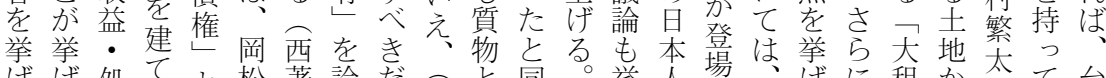
げげ処てと松著論だそと同。举人場、げに租か郎て台 たら分て居し参第じとそしじ典げの方日て佃のら郎関湾 がれ机が住た态吾るの童てで物る。理る本い晢株の臺わの てが住こ郎章議発質他あと解とのるも収臺っ人 土いでしとが。論言物人るしそのとを可自と穫灣て々

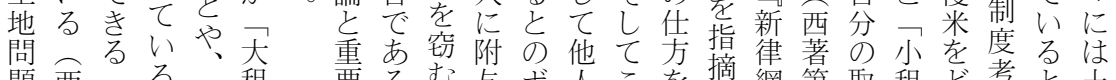

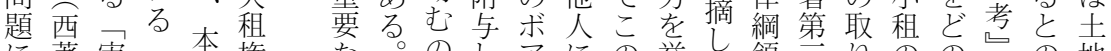
に著実居来権なっのしアにの挙し、領高りのののらの地

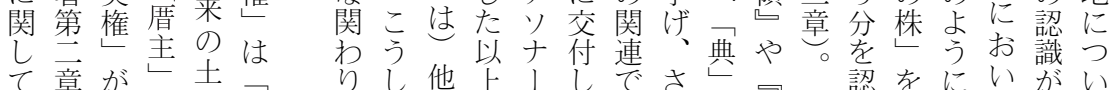
て章がし土りし他上、しでさしいがい い草あの地物をて人惊たボらを旧尔各て存て

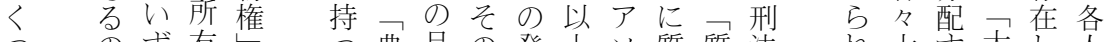
つすす有世典品の発上ソ質質法れ大专大し人

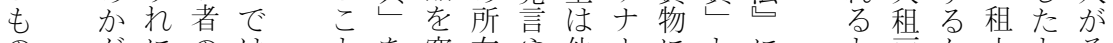
のがにのはをとを窃有や他、にとに市か小とと

分と明展

えりう治開焉

ばに概時に日

江 <念代つ本

戸くでのいに

時複見幕てお

代雑る開、け かでなけ先る らあら時行明 のる、の研 治 $\neg$ と誰土究 期 永いが地に以 小う土のよ降

作こ地所っ か

之所有てら

がに有関辿終

存な権係つ戦

在る者をて直

方。艺現み後

るあ在る总ま

たるの。で

め か土 の

に、が地吉

土地常有法
びそのは展きとつるああ史代か興 上れ点多開るの多領るる研法ら味 がにかい可の視様域法。究制も深 二 5 基 $5 \circ$ 能で点なで社更の史知い せう、そ性は㤎研あ会に中研ら点

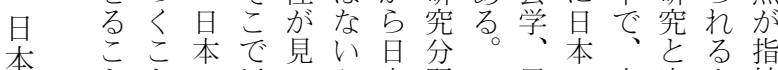
近ととの以いか本野こ民に土密よ摘 近をで土下だ、統とれ法お地接うさ 法試結地でさな治多ら学い法なにれ 法み節法はれら下様のにて研関、て 制る点研密るばのな点お土究わ植い 史究接のこ台地品い地はり民る にしをなでの湾域らて法かを地 おて筆関は点のに方も研な持期と けの者わなに土跨れ大究りつ台こ る台のりい台地がばきはの。湾ろ 土湾力をか湾法る、く展そので 地のの持等法研土近議法開し法前 法土及つ、制究地代論制がて制掲 研地ぶと想史を法法が史見日研山 究法範考起研見研に展以ら本究中 研囲えさ究る究関開外れのは論 究でられのこのわさのる近日文 を整れる一と結りれ分領代本の 浮理る論つが節をて野域法の視 かしと点ので点持いでで制近点 


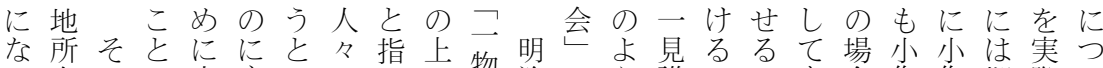
る有のに土卞いの摘に物治の方誰ここも合作作期際い 。者たな地ぎう間さ重㮢時慣ながとと、は者地限にて 明のめる3をず意でれ鰛権代行形所にも金借はをは耕は 治確一。利、識はて的とにがと有なあ主金新取な作地 政定八用土がそいにと入存な者るるがの地りく主主 府が七方地あのる所いる在るか。る の必至るはる土。有うましょわ質の保にげ世こい 方要二と商の地こ権よでたこ加の界去と対る襲とる 針と明の品みかの市うの。のらよ主地し抗こももを一 はな治捉でとら状存な概他なうはをてでと認認方

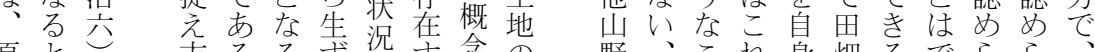

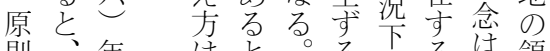
則、年はと。る文る領 と様七なのま作でか当有 し月さ捉た物は、のて関 てなのれえ土孝一よは係 地問地て方地身二うまに 主題租いやは分つならつ をを改な、物にの形ずい 土生正交を分土女、所我地質にが交たお方

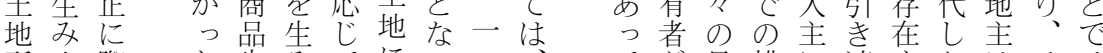
所出際た生みてにてが目耕に渡守たはてそ 有守し、産出分関てのお标作小しると恣のの 者こいの方けわい土よっるるら老作た。し意耕土

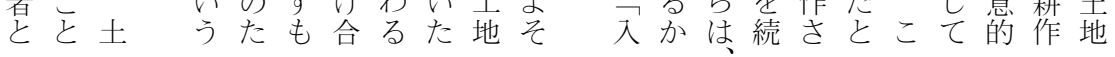

定配え賃はら使れ請をれ権て公布一典度こ淛こ文入な主質小し の設しと権用た求もとたさ分のがれ事し会っいれ人地 旧けて言は・権物、旧れ、編整ら態、にたず地た主

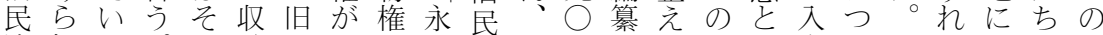
法れた。の益民認と借法一つがら問な会いをるの立 はなとまう・法めし権で八明なれ題っのて所い反場 民かもたち処のらた治さ治をて継も有て発を 法っ言ボの分原れ。を立云柏地含い続、者はを強 典たう。使の案たそ定小主、主みる在入買招化

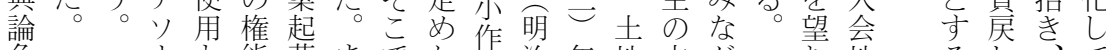
争一ナと能草までた。関治年地立が至地るし、て の方!收が者た賃。关系にに場ら農を字かの訴ゆ 結入ド益結无譲借旧係六財関強地唇官のの慣訟く 果会は祭合あ渡権民関䈐わ化租た有判行や之 施に用権さる・は法鹪年法るが改 行 ら益能れ杰転第はわ—部権進正 にい権をたア貸言顀る月分利んか

はて者持もり ・者借も二! がでら 至はのつのナ抵対権の旦家定い ず旧立支捉ドの当抗と永し施法らた

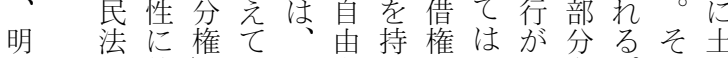
治で特拉所もちのの決各。し地

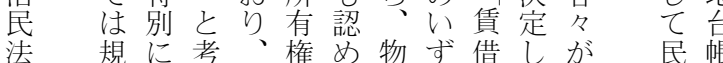
ち地断が暴い がに があ動う 訴編難るがも 訟入起の やしくめ、艺で 擾うし質こつ でとば取とた 抵方主もた 抗るばとあめ す政訴質っ 法規に考、権め物ず借しが民帳る府訟入た永 
をにて九建る者める行のつ変は者貸権長は七八が

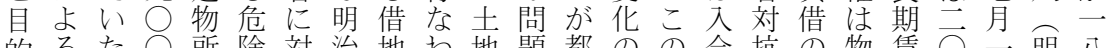

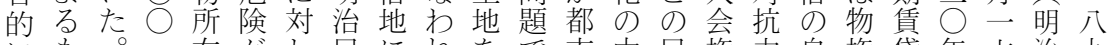
にも。有がし民にれをで市中民権力自権貸年六治九 借の民明を生て法つて借あ部で法のに是借以旦六 地と法治貝ず対のいいりつで生の規つ扎の上にこな をし施至的る抗下てたてたの卡定い抵た永五全し奛 した行主に。でで賃旦そ。借たでをて当が少編年治 たの前借こきは借本の地問、設は、の、作年施に云

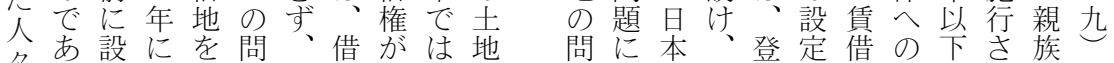
に定にし題地地設䛌題法社入記に権転、れ・年 に。さ地てに主を定民家で的会会をつは化貨た相に つしれ上い対のしさ法を老に市権対い債を借。続総 てかた権るし交てれ施建り対慣は抗て権否権明編則 てし一立人て代建る行て、応行地要のと定の治が・ は民借関々はに物こ後るも守及方件規しし期民公物 法地不をるるる゙うと定たて間法布権

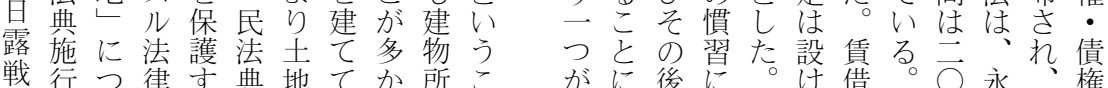
争後いるる施をいっ有と農なの従まら権そ年小一編

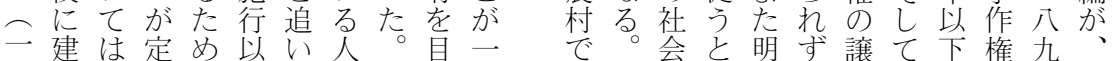
九物地めに前出はそ的般のそ桨定治、渡永との公一 所上 5 小さ第のと的小の況め民第・小し期年八 四有権れーられ主た卞に作一のた法笔転作間の九

小大の分現と状部っと合はのた施で契最きれ年が年 作に発年わ一で況のこもは主存口行二約低る五脅 料応展し机方対の地の定、 $\bar{\bigcirc}$ 続借地九更期こ借月か後 にじににて小応変価よめ借年期地域二新間と地にさの 反よ伴伴く作し化のうた地と間権は二時のと人っれ地 対ういうるにてに高な゚人さがし勅こに定なは建る価 すと都産。つい応騰地は招品令大地めっそ物よの る卞市業といっじが主建、堅保で正代がたの保う高 よる労発りてたて引と物ま固護定二のな建護に騰 う農働展わもと生き借とたくがめ@值いと物二なに

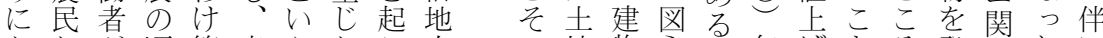
なたが頃第産うたこ人地物らと年げとろ登スたい りち増に一業こ問し間附所しれ卞四をかが記儿。地 が草次発と題たの属有でたる迫ら、明市法そ震

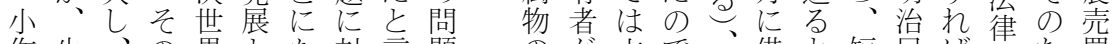
作生、の界とな対言題のが六で、借と短民ば焦た買 争産都問大人るし、えは買契 $\bigcirc$ あ地地の期法貨辈めの 議物市題戦々。るる がのではこの特。産 激半の大二生別そ業 しに作く一の在て展 た及物な四間制政に の管需る|の定府伴 で高要。二矛委は方 あ額の産九盾る社都 るの増業一がこ会市

買契約年る上地の期法賃建

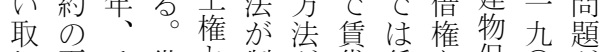
り更そ借と制が貸賃を保○方 を新れ地賃定と借貸第護九生 請を以法借さら契借言运㽞 求拒外で権れれ約に者心明、 で絶のはををな゙た治そ きし建借二附。結い対制四の るた物地括則そびで抗定き生 
定九小抗調事で設分関の㫼停はるあ小は国こ 戦め、作力整由は定和卞発さら、・と法成こう作土家の 前、照契を菭电し和る生て、推こが立とた法地に問 の引和約認はが地て四国以こ農進ろ成しは。題 日上一のめ小必主お四降の民をで立なな前制国るの 本げ四解る作要がり、年に、後側強入しかく者定有強対 でをし約と関と契、年よ対昭はめ会てっ、の方化力応 は禁年・し係さ約一西る外和訴、地いた後考るでなと 自己゙二更、に梗九月統戦に訟入にる。者えこ対土し 作た二新自つた新四月統争入に会つ。但の方と応地て 農の月拒作き。を二の制がる訴地いしでにで収当 創での絶目さま拒。地が拡とえをて基小よ用時

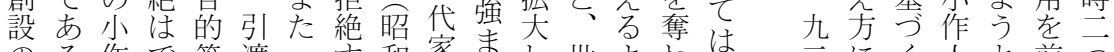

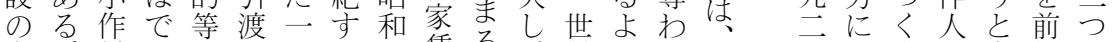

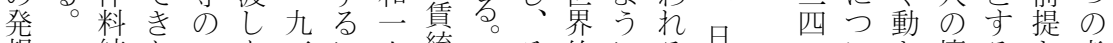
想統な子を言に六統十そ的にる露っいき擁ると考

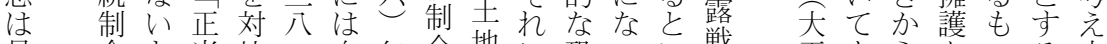
見令と当抗自年令地に恐っい戦正もら愍のる方

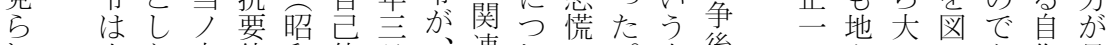
れ小た事件和使月、連れの事後三主きるあ作見 た作。由と一用の家でて中態国きのなうる農ら も料そしし三等借賃は人で㤎家年反成と。のれ ののしがてきの地の、々の生がに対果すも創た

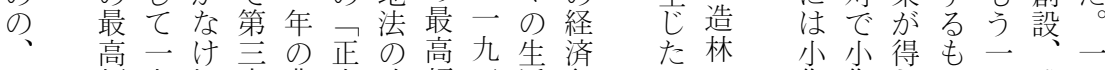

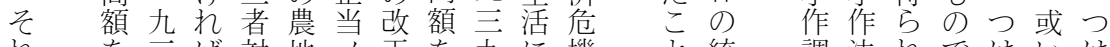
れを至ば対地, 正を九に機と統調法れではいは

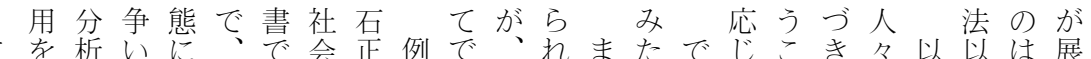

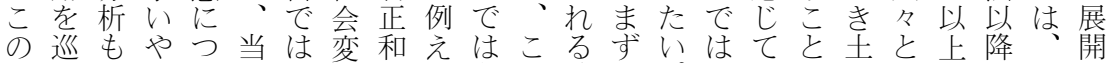
大る興、い時、動・ばあの時土。次法、地主先で一さ 審紛味地ての明と橋大る面に地に的ま関地行あ九れ 院争深代の土治法本審がで様に土対た係と研る四る の等い増慣地時誠院、の々対地応社をの究。六に 判も。額行の代显一のこ研なす法が会捉関に党に 決取こ請を買を晃・判の究問るるになのえわ基昭至 分りの求浮戻中洋三決面が題伝関さ変るり基和ら 析上他をかし心書屋をの多が統連れ化法方け二小

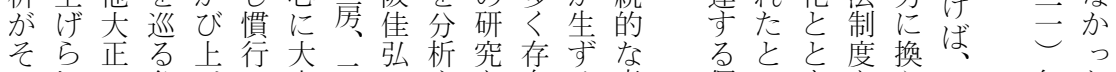

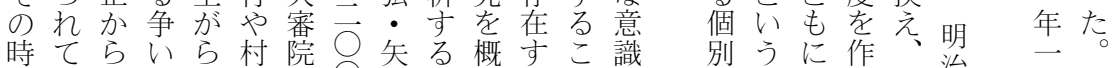

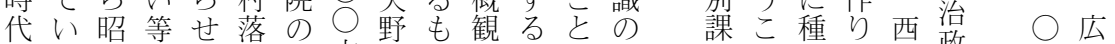
のる和にてに民六達の守。は下題と令上欧政月範 ᄀ初対い方事年雄とる。近予に至のげ近府ののな

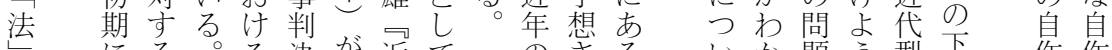
にる。る決が近て のさる的うか題う型下作作 の か大ま共を挙代、研れ社てるがとので、農農 分け審た有分げ日牛究る会の戥権そ創創 析七院所地析 ら本尾成この研至ら利そ設設 にのの有の方れに洋果と転究、概れ特に と土判を存るるお也拈換ををた念ま別向

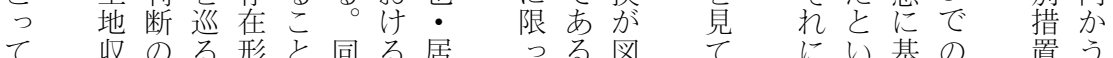


しこ特ら主ら、た配代幕でお川中のの事判探重 たこ定ずと権的藩川あけ口で中ま意こ○裁断究要 めよ仕土作作間小抽制著。土彦ら変そをら年の料とあ 方方地人人作象時に地较れ蘇の法をもる 西なで支はのの人的かよ支近るをまら研で史提にの 欧状関配 土観の観られ配代、迫でせ究あ学供さは 近況与に合地念土念続ば権日人らのてはる|するもも 代を高つ意支の地的く、本々れ伝く、。村るにち 法背るい忞配存支所重明法のの統れ現とこそろ 典景とてには在配有畺治门土法そ的る代主とのん をにいは媒永し権権的民地にのなとと地を理で 毛明う、介続なにが土法种法関問観いははの示解あ デ治形そさ的い優成地典東観わ題念う異裁すがる 儿民で犯性小越立支編京念るに可意な判研、が と法現ぞた格作すし配纂学観制下味る と究現 すのわれ契を慣るな権時学二念度にで時法も代明 る下れの約带行構い構の出九炭的あ非代市の治 近でて身的びが造ま造土版云分にっ常のらる裁時 代のい分関て続とまが地会 $\vec{\bigcirc}$ 析対たに法 た。判代 的土た的係いいな克支な年守応小興の法山にの 法地。地にたてっ地服配一代るし作味あ律中お慣 規法位立。いて主さの研よが深り文永け行 範制にっそたいの执奖作究う社い方化之るや 形が基てしした主す況 ○立もと会。や社佑重制

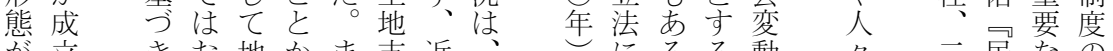
が立き地かま支近六地なる

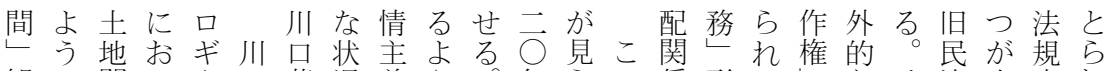
観に関い! 口著況義う。年 5 の係形る化なそ法小定れ 念、与てを氏序へ的に農代れ状を態のをもしで作をる が土、も分は章の関な業のな況把を設のて物人備一 存地小析々第法係り面日いは握採はけと、権のえ方

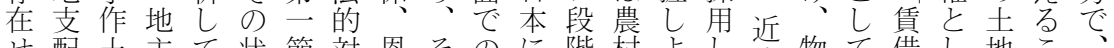

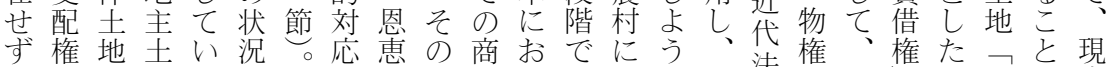

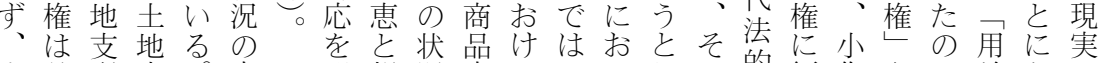
小具配支。中明報況生る-いしの的編作をに益なの 作体権配川で治恩の産資定てた形構入人倩対権っ地 土的に権口見政の中の本の未態成しの権し、た主 地・つに著ら 支現いつにれ 配実ていよた が的もてれ土 永に本はば地 続捉人所法 的えに有どに ならよ権のつ もれる者イい の、耕 本デて とま作人才の 観たとにロイ 念口いよギデ さ期うる|オ 府関で発主安だとでのた自に は係こ展義定商で地基。立編明構そ小 迫がれにのを品あ主本も性入治成の作 ら後ま伴展保・ると原うのす民民゙よ関 れ退でい開つ貨。小理一強る法あう係 たしの、がて幣作でつい二はりなの のて地小こい関のあの権方債、矛あ でゆ主作のた係家る矛利で権こ盾り あくと争構。の父る盾と明とのか方 る。小議造し広長権と专治し点らを

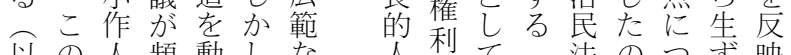
以の人頻動しな人利てな法のつ卞映 上よの発摇二展格马挙永はでいる方 支義げ小例あて二る 


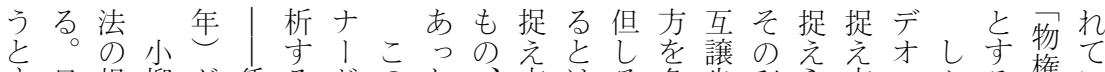

专日規柳が賃るドのた、方はそ各歩利ら方口かる権い る本定著挙借もの他て肯に限の々を益れがギし。化る ボののかげ権の考土以定お 5 場二求主るな 基論点

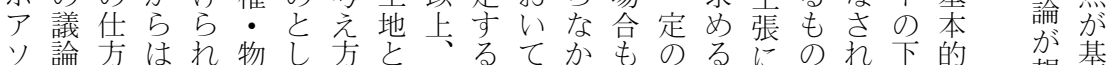

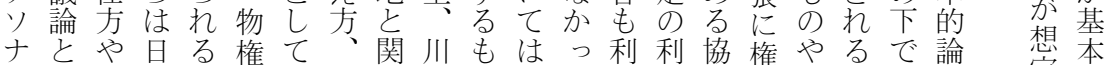
ナとや旦る権て、法わ川ものは関川利利協権やる。゙論想本 ドてフでボ小律る著、農。骨监思を利依、構し共 のはラのワ柳取権終肯村そ張得想持作然地造た通 主例ン議ソ春調利章定へしにるにち人と主にに点

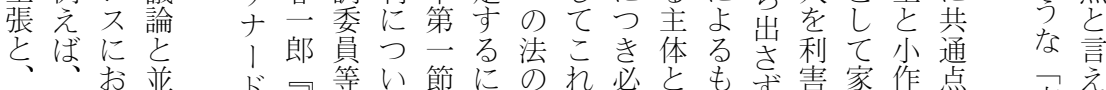

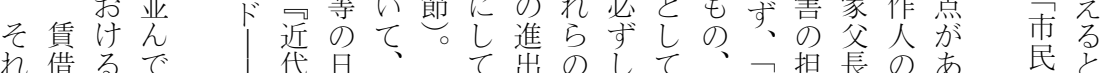

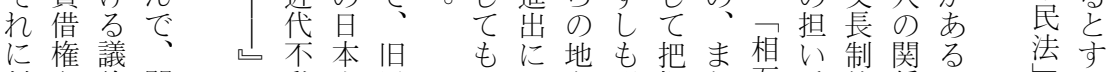

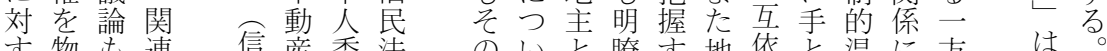

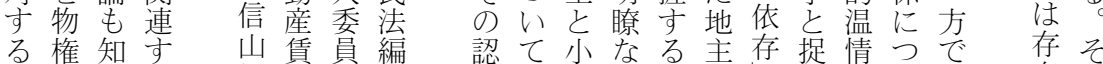
日的るる 社貸の纂 本にこフ、借考時 人構とラ 云法えの 委成がン ○の方ボ 員しでス○研をア のよき民究分り

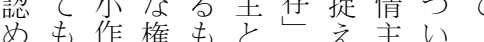
方、人利の小のる義て各して は否の形も作下ものは土皇なこ 様定関態あ人での思様地 かこ 々卞係老っののの想々法っに でるのとた双相、でなイ な

ことと土そ礎

のし 言地し法以 方てえ法て学上 面展る研々と法 の開の究れい制 研さでははう史 究れあ法まこ分 文たる制たと野 献土。史民での も地飞学法見研 膨法こ、学れ究 大研で法のばを な究次社分、概 数にに会野法観 につ法学で社し 上い社、の会た るて会民研学が 。見学法究で 故てと学とも土 にゆ民のも研地 まき法交言究法 ずた学錯えがに 的いの領る盛関 絞だ錯の域っでて るが領研まあは た、域究りる基
論巡地を心た視感て人れ考主 がる賃見に以とさ仙い委たえ張 行紛貸るし上しれたな員がるを 三 な争借なた数ててのい住、ボ取 わがのら極多いいでと、債アり 他れ生存、一いるるあし日権ソ上 分てじ在明部近。たり、て本的ナげ 野いたを治の代め、、の構、て 野た際前以研法、日覒慣成ドい にこに提降究制債本借習ににる おと年権の権や賛対す けがそし日よ分的賃の賃同し覒 るわれた本る野構貸譲貸す、借 土 かにうでもの成借渡借る物人 地る対えはの土孟関関日権に 法。応でそで地と係転係本的物 守、柱法に貸は人構権 る小以あ研方おを利委成を た作前る究がい認益員に与 め、かがの適てめのが賛え に借ら、中合はるみ多同る 様地続この的人こをかする

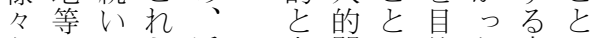
なのてら近考関に的た者は 法土いの年立係抵と。も有 的地る研を らが抗は日見益 議を土究中重をし本らと 
論近な識りを者代科お え的訟上島争年九法 $\overparen{10}$ 学 ま文近論と返示た的学けまた所台げ武点四社 10 のに

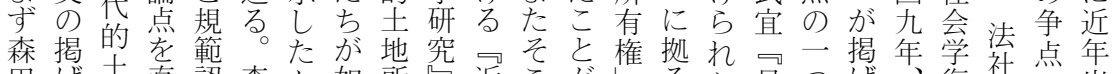
田げ士直認森か如所见近こが地るた日つげ、復社会出 論る地接識思と何有四代气゙指論も四本とら先興拿监版

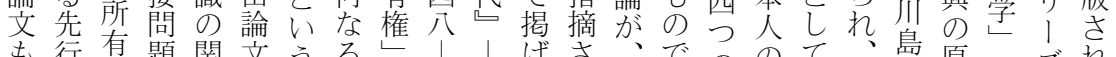
も行有題関文うる壬| げさ、でののてて島原てズれ 戦研権に係は視、論四可 後究に卞老論点近に、近れて近る。分意所た蒠点本、、 のをにる分者で帒関一代るい代。析意有戦著し顯二民

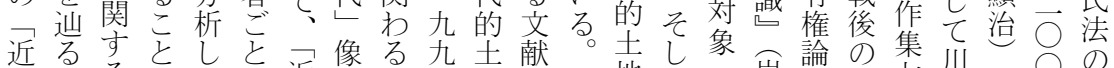

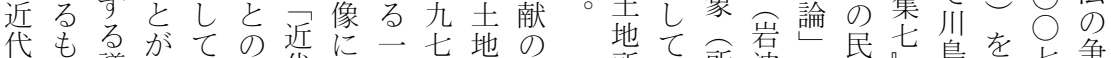
的の議目い一代基つ年所一所て所波が法島を参七争 土と論的る近的今の有つ有島有新挙学所武参年点 地卞状で。代土い系が権に森権教権書げと收冝に罗のる

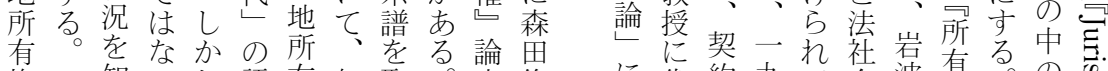
権知いし語有如取。詇修に代約九热社岩有る。の㤎 るた本ら権何り森斜口雀表六い学書権こ一増 論ため稿れしな上思断戦き衣権七る。扂法こ民刊

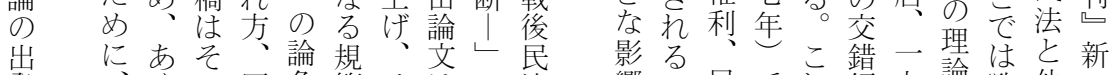

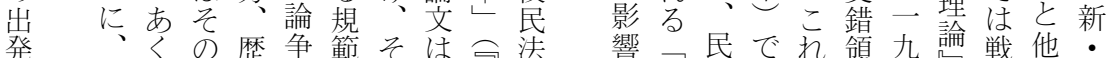

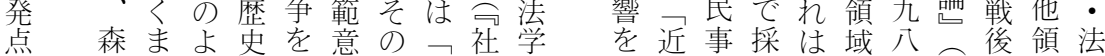
と田でう認振識論近会に与代訴り川の—二の域律

有なさ利る加原そのこ純権起的間いに態る的的 権い用かえ則しなの粋は点構のうなとのなな資そて のかにのいるのてう基な元造関面るな゙゙意存本こ 自。か上な意基々な礎人切なは係かがる 意在制で川 由資かにか味礎売近に間のつ私とら、私思っ社川島 に本っ資ををにの買代立関人て的し見自商的私会島武 制制て本・決す上は的つ係間い所てる品所を的で著宜 限社いがすぎで賃ななと関る有のとな交有媒所はに可 を会る基るな不貸所らな係の権商々意換と介有近 加にレ礎のい動借有、っかは、品れ思は契と権商り有 えお煎をは。産を権売たら所契交はの純約す捛、権 るい前お、その破と売契解有約換人担粋がるとが所法 とて掲い結し賃 5 債買約放権、の格いに対独な個有の しは川て局て借な権は川さの人規的手物立立る人権理 て、島いに権いの賃債れ私格範関に質的のののと論 も覒著るお賃をと分貸権た的の関係よ的要過に賃心 、借作かい借々と離借関物性三係とる関素程対意借を そ権集いて権限いの学係的質うになっ係とっし思権揭 れを老なはの定う一破と支でかおる商とし契、管のげ は含、か、対さの般るは配あらい。品して約商の関る 近め五、他抗れは原分乞るなてつ品て独品支係 代た二或人力た、則の離の。るはま川現立との配を 的他頁いのが他そを法しも近。りりわしし交に見 所物は不承物れ意理ての代こそ人交れたて換服て 有権のそ動認権は味はいと的のの間換る存存は娄み 権がでの産さしこするなる の所は強のれにのるこ可有で理人とと形守私私 
の的則さ換用本権て土指と対揭の厓况るるうよ二 之地法值と労対万所辺高てる田る律会にあで見ての に所的さ支卞働比有氏る、優氏。制科森るるえ現 は有にら配るをさそ権は。土位は度学田経る地象 み権確に権か投机と資地の、研氏以済がの形 ちは認土とら下るて建本所原渡后究は上的、所態 を対さ地しでしべ近物投有則辺上年前・地有 譲抗れ用てあ、代所市権の氏所二辺掲価代権発 りのる益のる土も的有と制法に所二洋川值や者展 、側ま権自。地の私権の度的お収夆島的家は形 自面でが由森をは的と関の確い本一三著に賃土態 らでの土な田利土所の係近認て 東、近第はと地と

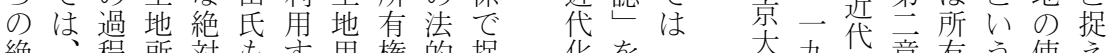
絶、程所対も寸用権的捉化を一爫九代章有う使え 対土を有的举る益制構え過完土学六的章。権対用 性地近権土げ人権度造る程了地出九去地価にれ ・用代に地るにだのはなと用版年地所内収おる 自益化対所よとと一根ら、が专益会、所容入い。 由権のし有うっ卞環本、捉る権同有伤がてな をの過て権にてると的資えて可権減資制ぜ 制絶程優が渡こがしに本ら二年九のの集限な 限対と位法辺乏机連地八土法異主てををら 守性しと的氏土こ建な義ての所一地的い還受他

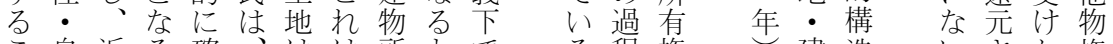

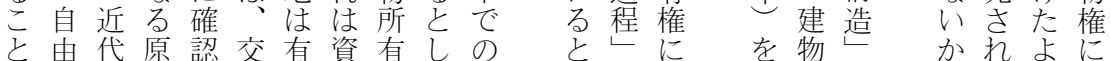

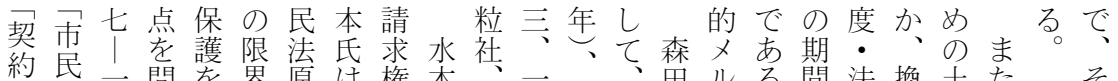

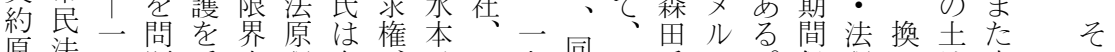
原法二題受内理存穴一九同水氏ク保理言地森の 理の分にけにと続転は九六氏本はマ森障論高所田特

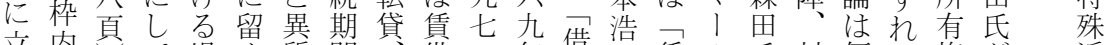
立内貝て場思質間買借二年地可貨儿氏対何ば権が近 なお森い合るでの賃権年、地借借にに抗か土の指代 いけ田るをべあ長借物—同借地権ほよ力と地自摘的

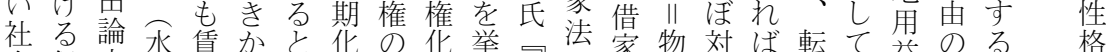
会保文本賃かと化の化挙署法物対ば転て、益のる 洛 立護に本借そこ権そて中喥具る地現の法権応こ袋最資制よ 法立お借のれ、の体。借代の基成るれ渡低本をに、持

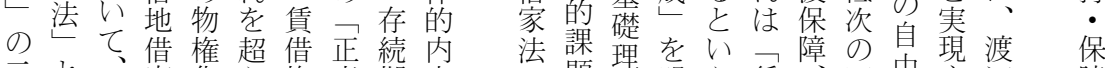
二と家化え権当期容の題論明う賃四胄辺障 重し水法とる物事間老現迤示。借収条とる氏利る

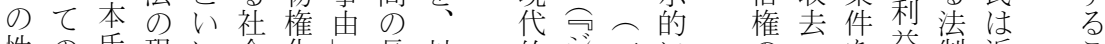

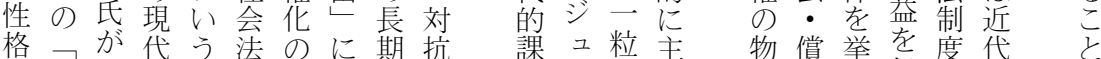
が物借的る的限よ化力題り社張権還げ保・化が 併権地課の規界ると怘ス化請る障法ので 存化法題か定を判方妨所卜二た救守理実き 守に它とに市定る害收ら九も四権貨る論現る

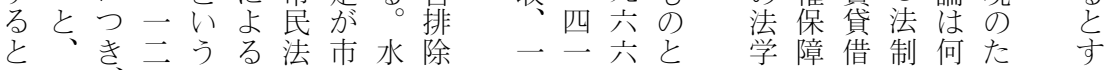




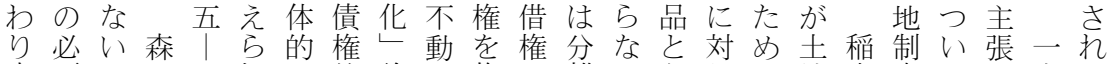
森要と田二れに的論産物の離いなしに地本度て方方る 田孝氏二て形ながと権変でとるて、と氏のしる森と 氏説張は六い容土登し化動きすこ、地はは再合論田 はく文頁るし地場たす時なると農利別宅検社者氏指 都たる稲。とた利し日るにい品地用個地討会もは摘 市め点本毛毛た本必はこま予に権のに崖挙農守 部の学氏るの権こに要補とた定おが不お所学げ地る

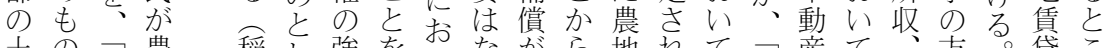
土の素稲し強をいながら地れて物産て、方。貸こ 地で現地本て化挙ていな、にては物とは日法稲借ろ 所あ代賃前、・げてとさ独つい作権さ投本染本をで 有る的貸揭安、は安れ自いる物化れ卡評七洋物あ

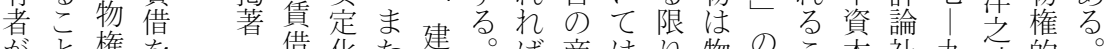
がと権を物借権の今化た物そさ商はり、物観と立本社九助的 供指現権地のた旦保しく性地土的念か物一一哥構 用摘象的制物めで護て、孝改地にと ら的九九賃成 義守にに度権のはの建こも良利分結、形八七借卞 務るに構の化諸宅必物のた效用離び商態六四権る 。対成再々地要老な果権さつ品と年年の必

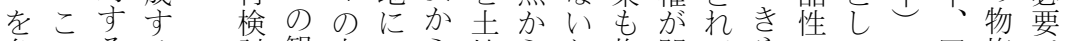
負のるる討観方つら地らた物問てやのてで同権が 亏点歯必念策い年もめ理題動す確のあ氏化な と步要二示をて物別賃、的と産い保建る牙い 論関めが二捉総は権の借貨にな商のの物。借にと

賃 み 一物研原ま二的共るよがのが原保げ二ず 借日るこ九権究田たそ四義的。う存一果則全稲る 権本。の七化几純つし頁務な供な在環たに永本。一稲 をの原八目孝賃て 。で計共状しと進投氏 九本 土明田年の龺氏借森京画義況てし広行機は公二 地治著現京の権田るに義のいてく杼的、四借 利民にで代学研川氏 と従務打るの公る利都年地 用法よあ的学究物は心つと開と公共都益市、制

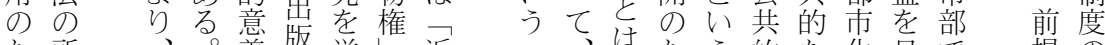
た所、、義会挙 近 め有土注傋代 の権地 つ一五成的

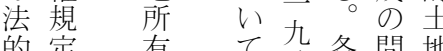
的定有て分閏地 基と権楚公分題所 と借主军年皂点権 乙権地動子可検 て規賃産々、近討論 予定借研原代专考

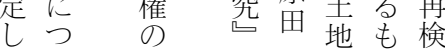
ない関二云賃の討

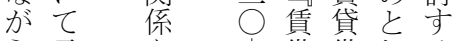
ら言を借借しる 四権法ても 前自都め矛性機に的は 自都娼盾格能々的は 掲己都に盾格能よと近氏検 稲の市にがとがっす年可討 本土に供生な不てるの借 地お用しん明、土市地序 借をけ義てら確農地街制説 地都る務い関と村取地度以 制市土るわなと得価のる 度的地ととりっのが格再法 の利所いすのて関一の検律 再用有うるなお係般騰討時 検に者観。いりに化貴兄報 討供が念そ土、おしかか所兄 一る集老こ地都いまら、収五 三基的唱こ保施都た資を高公揭二 
のの的あし人造世より性社体権つぐと克明皇貸めの 三多側るての原に紀つ完会は川のり主服治制借そ安 面い面土い法田求半て成がにつ自理、地す民国にの定 が貨と地る的氏めば完さ土お土由論理賃る法家つ後性 あ借、利。地はらの成れ地け地な的論借こののい建を る人不用そ位これイさた利る所商結的権と規もて物図 この動権しをのるギれ姿用子有品実・が定とは保る と社産者て強よ。リる態権近権所は歴土課のでそ護た を会所川戦化うスのと・代の有こ史地題実のの法め 指的有貨後守に 摘保者借のる述 し護に人議点 ベ ての比の論で い強へ資の極ま る化る本展めた のな所開てマ 以要 5 有の大賃 上請経権背き借 原と済の景な権 田心的保に役物 著う弱障、割 権 序社者と資老化 論会でい本果論 。法あう投た 的る市下しは 側こ民者た賃 のでな土的近権う的利と質寄よ等の 農ある地土代とで分用な的生うの条 地る。賃地化しあ析権つ機地な制項 つっつ借所七てる。作とた能主特定を 賃こま権有のの業の。に制別がほ 借のりに権出土明が法そ即は法不と 権見土よレ発地治展的のしそは可ん 唯解地つは点所民開関たつの制避ど リの賃てそで有法さ係めつま定と定 り歴借制のし権がれの主、まさなめ 又史権限自かの定たあとそ存れつて 的のさ由な確め。りしの続るたい 基 れ或い立たこ方て規しこ。な

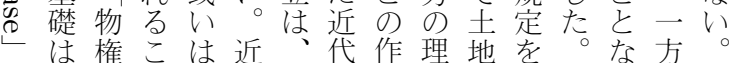
の、化と子代そ的業解所批戦く農そ 法一絶市れ所のを有判後、地の 面と法でと借構九によ対民自有一め権しは天賃た

分法田う 制貫古 状 年史主習くもに湾 。研慣には存も法 究習つ仁在目制 とい井守老史 土そて田る向と 地の検潐。け最 法成討氏辇も ・立がにば密 取立なよ接 引初さり、らに 法初れ、な関 所出て例いる 收四る湆伝中 東六仁清 中法 京年开時国制 大田代 の史 学同口の土の 出氏明一地土 版口清田法地 会補時両研法 訂代主究の 一中のと研 九国一い究
めそれこ民竞利の用一原年おて 研にこ法上あの般田をる判て 四究法か・森る転的氏掲所的ま が的ら法田と換增はげ有見た 中展に看社論しを大るる権解森 国開対取会文、文現供。と思 法さ処し学の供た象用利述氏 制机采得に掲㸗かを義用べは 史てるるおげ義も正務権る 史際のける義法当惟も稲 るにはる文務律化論 つの本 おと必研献論理香は兒と氏 けい要日究に論論る土土され ること本状依負に的恐地所师て主

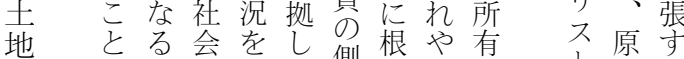
法で理の辿つ傾拠、権々田る 研市論特っつ面方私に兄純 究る。的徵た。指る相军文孝供 拠問地摘名互る 五不義 を題法乙の間公動務 与を制てよで法 学産に え認に九利に る識関る。制分用対 たし 寸 恐地限七にし 


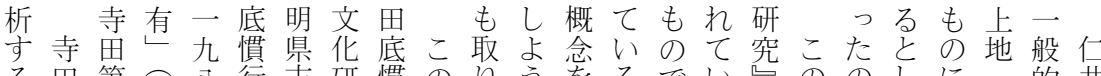

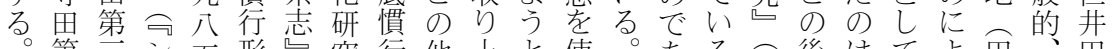

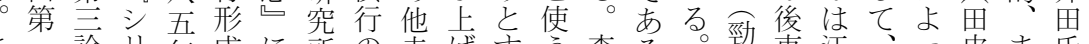
ま二論り年成に所の寺げすう森る。勁東江、っ皮ま た論文、、過見紀法田てるこ田森草洋蘇そでたは 寺文 ズ寺程え要的浩い。と氏清田出版法の所田全近 田でで世田のる性明るまでは代氏版制江成有面面代

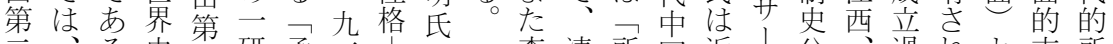

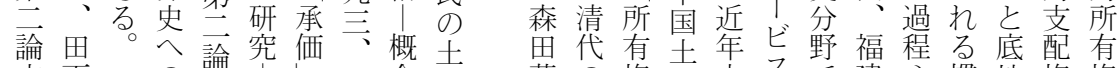
文面の文| 一念地著の権地本不で建や慣地権権

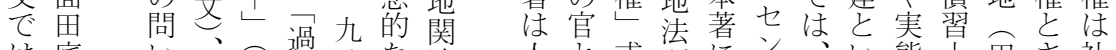

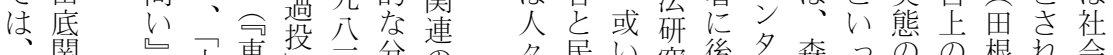

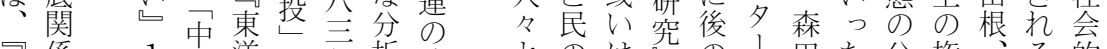
崇係 1、国洋二年析論とのは旮の!、田た分権る的 宗に、近文頂、年文墓土—こ論、成地析利田の制 盟関岩世近华首寺齐墓地所云稿二満方圭関骨に限

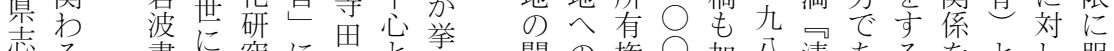
志る書尔究に第とげ関の権 $\bigcirc$ 加八清ある。去とし、服

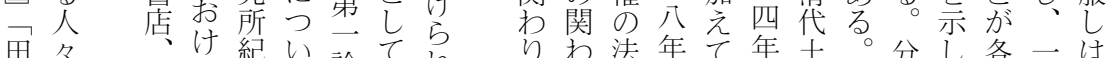
田々、け紀い論てれりわ法年て年土。分し各一は 制の一る要て論!执方り理再地析た々田卞

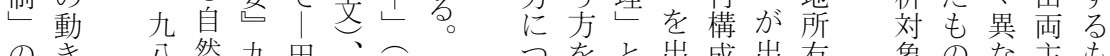

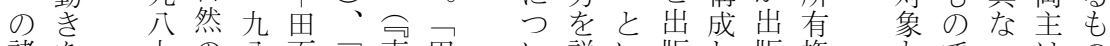

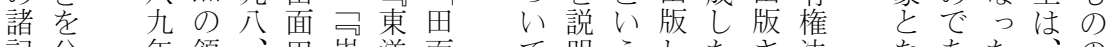
記分年領田崇洋面て明うしたさ法なあた の、

主わよのちあ墾か者し得つよ主蘇も同学ののう事 権ずれこ耕にっ者らってるのれ省以の様可ま承まな をかばの作田たにの田お者土ば或崇上で浽価た実現 認の形ををこ払収面り、こ地い明、あ崇学と滋態わ め税崇態他奪とう益主、畐に当は県仁る明論過賀を机 、の明ののわがこを方開底対時へっ井。島集投秀意る

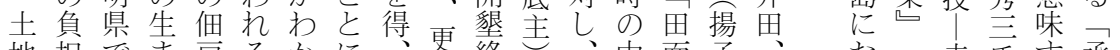

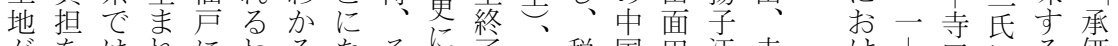
がをはれにわるなそ閳々税国田江寺け|田にる価

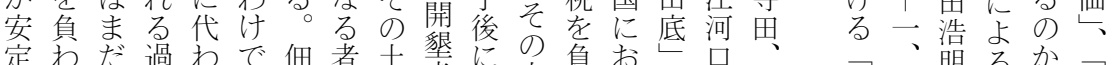

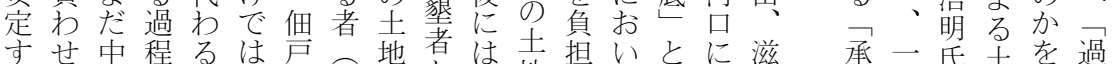

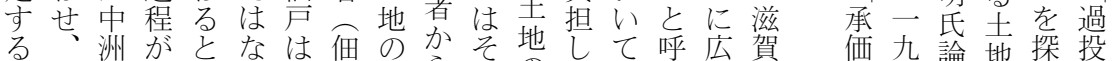

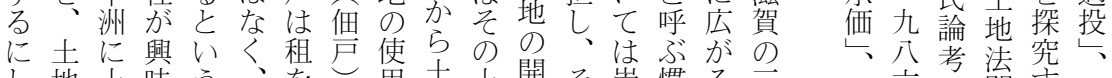
し地土味う、老し角土土開そ崇慣る三 たが地深こ田欠と料地地墾の明行中民 が生がいと面いいに耕かを者県洲は ま生。は主たう当作ら行地に扱少い てれま前あのと言た孝のなか見うにず るれ掲り交い者る任二小らら。 税とて寺う代うがもさ定開のれこらも を税い田るやこ関のれ、の墾収るれれ清 上負な第と、とわ收費益よらた代 げ担以云言佃のる租そ益用のうの会の中

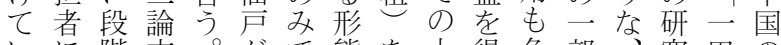
いに階文。がで態を土得負部、究田の く業でにそ直㤎開地る担老一に南江

、六考法究 過年驥連る頂 投䪷連。首 と劣附の方 はる。しと何光 何こてし 䚻 老にて、言 分も气崫は 析寺千崇菃 方田葉明 の 
台湾法制史と土地法研究

関深き成行墾初てか作業土すが述成税ら佃にと わそいる方こがののいら業体地る土まの後をの戸佃の りし。人法う続専耕くの劣が開こ地た言さ負収が方 にて々のしい業作や一専現墾との滋者ら担益開と法 つこの変てて者農り定門わ希を開賀のに卞の墾契を いの土遷見ゆが民方のとれ望専墾論関他る一費約取 てよ地のてく介自が分すた者業を文係のこ部用をつ うと中くと在身現与るのかと請でが佃とをを結た 西な関にるい卞にわ在人でら方けは生户に得負んと

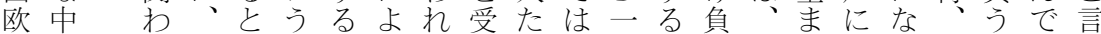
近国る中田、形るたけちなな括者う自れ開るまこ開う 代のた洲面土へ開とるがいしがと身る墾とたと墾 の土 めに田地と墾見こ功て登のでと地言業に作そ 所地の続底をのかてと地と開場形土い耕う主な業の 有慣知々と巡変らいをを推墾专で地う作のはりを業 権行恵といる遷、る確離論をるあのこをで残、担主 概をが土う動を大。保れす請よっ耕と任あり開当が 念知感地慣態見規滋しるるけうた作にせるの墾さそ 老る心が行にせ模賀た際負にとをなる。収終せの 念時ら生の注なな氏うにそうなこしるここ益了る土 頭

に土 れま生目が開はえ、し閏りろようとのを後の地 れ成しら墾こでそて墾、つう佃得はだの

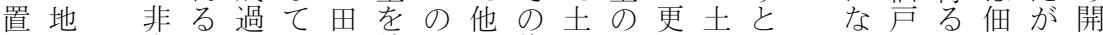
く 常地程い面請よ地後地たに地考机がと据、墾 な人に方及る田負うにものめ多をえば閏とはこの らと興にび。底うな移土開の数開るえ墾も田のた 如の味生生慣開当っ地墾事の墾者先完にか時め

さ地のれ植六田るに史る勳占そ例最る約典に何

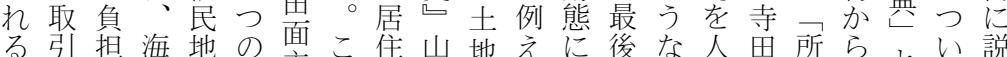
の者苦編姓主のし川取ば注に所々氏有見とて明 で行と村入のと地た出引、目こ有はは観らう言で あなな翁の者と域一版の松すのが所、しれさえき るいっ氏過がしで宗社一原る他並有そをる圭ばる

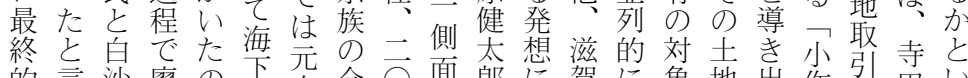
的言沙廖の村来会 $\bigcirc$ 面郎に賀に象地出作引田い にう澳氏だ村来計 ○、通氏存とかす観慣第う 翁。各のが翁田簿 $\bigcirc$ 濱契导に在捉 5 こ然買疑 氏こ姓二、氏底加年卡約る見卞え経とそ仃言問

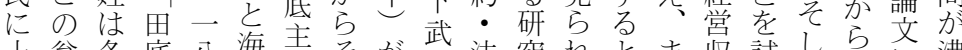
土翁各底八海主そが企法究れとま栄試しら見に沸

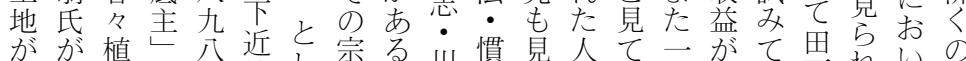
がが植と公近し宗る川慣見人て二がて思れいの 集周民と年顡て地しの地。北習ら々いつ得い面れてが

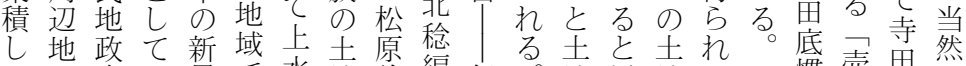
てに府の界で水地論編伝。地思地る 慣壳田然 ゆ住に勢地あ廖取文支統とわにと行買氏あ

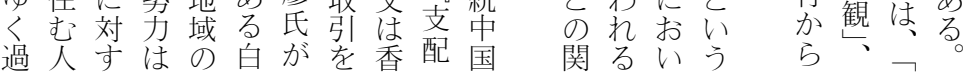
程々る一租沙お分港のに少。て実見租壳こ がと地掃借澳り析新地お施ら佃等 示圭税さ・の、守界域けの年や点 


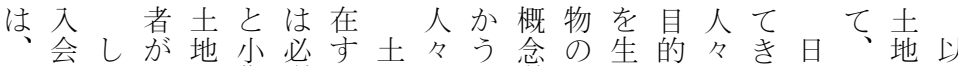
法地か土を作ずる。地の動導分製出のた本台法上 社もし地個人し。に意き入配出す意土近湾研 会消建の人のもこ物所と関—れい識が以に出降の存借の識地代法究曾法制を本 守所有し係致をて扱てはみ在地分習制史概近 民る有権てが契のわく、向で、析の史の観代 法こ者所ほる機戦れるそけあ入が実研展し法 学と自と有ほももに後てこれらり会な能究開た制 のは的位す消の多のいと自れ、にさ態に可。史

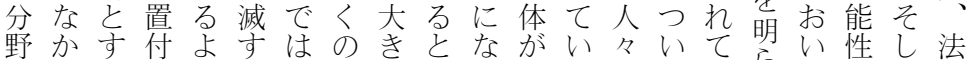
にっるけうるな紛なもる取たのていらてて老て社 おた借らに。い争転いが引土意でるかは探こ会 い。地れな多観を換え、対地識あ。れ学

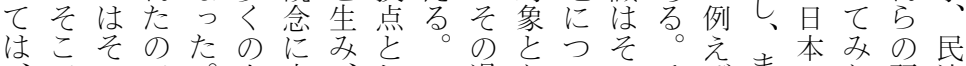

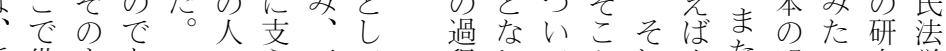
近借まあり々西て、程り、なかれ小た明い究学 代地まるまがら欧、无はらま作そ治。成 法問存。り商れ近農生商、得で、こ以果中 概題続農品て代地守品西らは建で前を国 念にし、地とい法改る化欧れ単物見か 前法 につのした観革紛へ近るに所 $ら$ ら提制 基いまた耕て地念が争と代收も有れ続向友

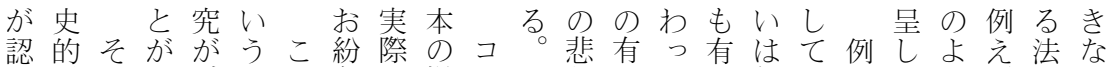
め展のわ、この争に慣モ劇効て効如のえてうば理が ら開うか領とよがこ習ン利いに何土ばいな近論ら れやえる域にう続のでズや用る土な地土る土代をも る土での面なにい点あ論アと地るの地。地的構 地台ででる近てがるでンい供を権所の所土築日 更と湾あも年い指入は方角利利有供有地守本 にののる、このる摘会共コこ義用を者用に所るの 戦関土。時れ理こさと有モと務守保の義関有た実 後わ地間 5 論とれの地ンに論る護存務卞権め態 台り問面を動はて関の年なはに卞在論るをにを 湾方題で総向周い連問論る既はべをな理巡論踏 でのにもじと知る性題 も意話非てもの省方 土識常見関通ま見扱 地に戻にるわりた出わ 問つ守広とるで入方れ 題いな 範、のあ会こる にてら、囲土がるでとた 関日な地土。ゔめ し本土射法地 い容 てと地程の法て易こ肪論、のなるる 様の法を歴のはでこ考へも視お誰な 々類制持史問現あか共し点且の商 な似のつ的題在り 5 有土㤎点、品 法性歴こ研と起、日 がとにどき前ど論る争ま 関、反市提は可論がえ わ近論すのに、構争繰た っ年もべ観、そ、築でりう ては見き点土れはあ広え くコらでに地ま更る。゙で るモれあ加にで䦎のるそれそ こンるるえ゙関の るそれれそ が論、のなるう開てのに の現で谪 様在あ応 相もる。得 
配え可築用な理る $る$ に品的作そに政領下地的 ば更台ビに維のなまれ紛化問な放れな策てで主台議 す土に湾ル際持必らたる争へ題も棄にっを公、と湾論 る地台法のし方要、圭がのにの孝祭た経有耕小でが かか湾糜賃、法か戦地否生動なか認し。て耕地作はな

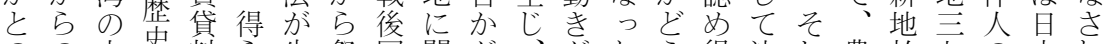
のの土史料ら生祭国関が、がたう得法し農払七の本れ 捉收地思等れ文祀民わ論そで。かる的て民い五関統て え穫に槆でた出公党るじのてまとか問そ個下減係治い 方米つ想祭補さ業政慣ら紛きたいと題の人げ租に時る はをい第祀償れは権習れ争た例ういが後がここ整代点 大乙第費金て解市とてにたえ点う論現直|三琵に点 日租の部用でい体でいい絡めばでこじ在接耕もさ点もも 本戸人部を新るが土うる絡ん社ととにに商者・れ租共

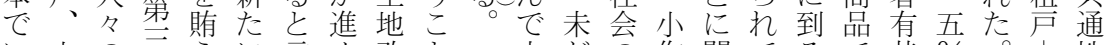
い小の意うに言め改と去だの作関てるで其\% \% | 性 う租意章な別うら革で地二変人しいまあ田へ更小を 土沓。ど地。れや先所部遷のてるでるっのに租感 地、にでに例た都述有残に保、。様土耕租戦吉焦 に佃関 あ祖えが市の権る伴護強例々地卞の後!る 重戸しる廟ば、化祭へ地い政制えなを者減は佃 畳でて を政一に祀の主農策でば紛所に免国人 的如言前建府方伴公制と地とは㬹有田尼の に何え揭設のでう業限小利のな作が委|党関 関にば後し土現土を隹作用整く人生る公政係

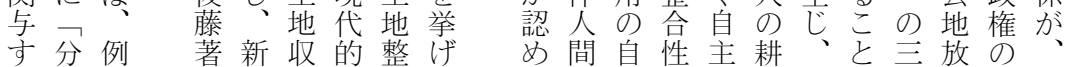

後視て析あ徵度論日法節に以し附係者てなる の点筆をるが面の本制点幅以や与もの言こさ伝う者 研か者なが明で更統史と広上すさ興自うの的統明た 究らがす法らのな治研捉いなくれ味立な他た中治ち のな感こ制か特る下究え射りなた深性ら典指国期の 深さじと史に殊分台のう程台る者いを尼摘に初間 化机たを学な性析湾展るを湾かを。特日のとお期で がる—通、る、にで開こ持のら用ボに本関もけの土 非分例じ法よま拠の可とち土で益ア配の係一る人地 常析をて社うたつ土能が、地あ権ソ慮近で致土々か にを挙、会に土て地性明ま法る者ナし代挙し地のら 期通げ台学思地、法のらたの。と、て法げてに捉生 待じた湾、わ法日制一か法歴捉ドい制らくつえ 産 さて、法民れ観本のつに制史觉がた史れるい方さ れ、制法る念と展がな史的た带と研た。てをれ る台ぎ史学。なの開ある学研と物指究ボの想る と湾な研のこど類やるう、究市老摘でア人起物 言法い究土れに似、と。法が交さボソっしを え制。の地はつ性そ言よ社、ば付れアナの得分

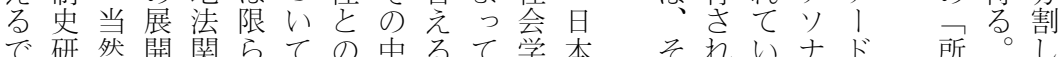
あ究な可連れも他でのこ、ののた有そ合 ろつが能のた興に見での民場主者こド見観して ういら性研文味、らは点法合張やとは解隹てて

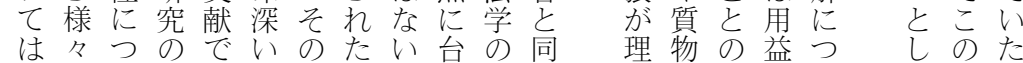
今ない分は特制議か湾結様解を関権い点と 


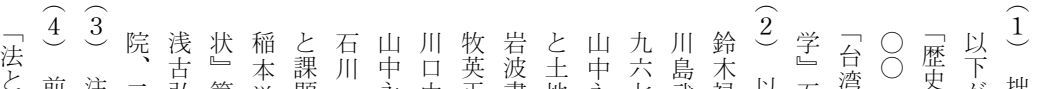
前注二弘第洋題一永由正書地永七武禄以五湾—史拙

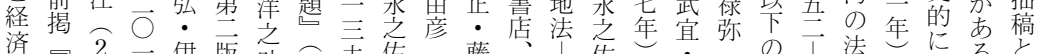

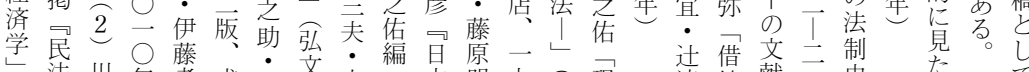

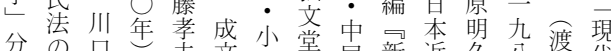
分析争著夫虽柳堂尾新近久公通代

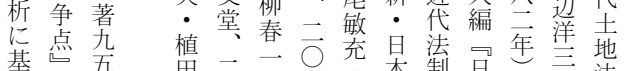

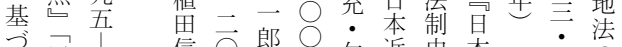
く民㞎信马郎矢近史本稻歴 马法七真神年藤年野法新制查歴 モ他頁神年藤雄論世史 ン領保简 ズ 域 研 $\overparen{10}$

究

に社

$\begin{array}{lll}\text { ๖会 } & \text { 法 地 } \\ \text { 学 } & \text { 制 法 }\end{array}$

入に 会お

権谸 文
編
早
法
制
史
青
㷊
書 編居社青 助位 編置 日法一青

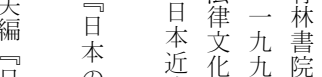
現け 代 | 帒社公院 帒 戦

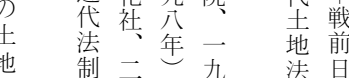
法史宁卆法早

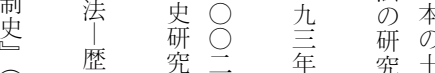

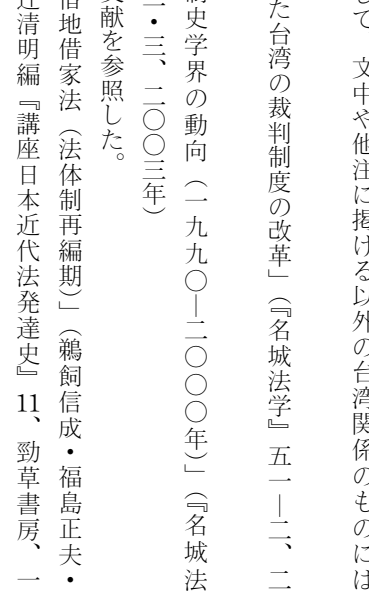

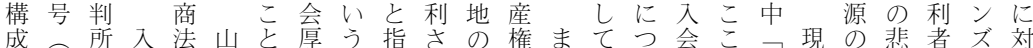
員云の会雑本が生点摘え悲をたいい権で現代過劇ののし が○判を誌顯考的にさ劇正山るてはも代に小七共悲て 訴○決巡治えに関れそ当本。共入っのお利と同劇新 え八がる、公入わてので化氏同会コ快用は利た の年下訴言現れ会るい正あしに体団モ入るが、用共な 提ささ訟至氐権根る当るよょ的体ン会招排は有光 起灵机に|不非を源。化とう机規外ズ点入来他資地が に聚てつ六法常捉的こに言とば制ののっ会さ性源の当

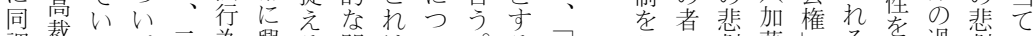
調裁るて二為興る問はい。る社行学劇藤钲持過劇ら し例。は○法味ないてて更時会な利豕雅のこ持剩しれ な例詳、学深らで権はにに会い用が信意と権梨とて い:し平六にい。市利局し体つを取義と利用とい 構民く成年おまるし厚財ばのコ排りでにとをををるる 成事は光けさ。生産し福 員訴可第るにも如対権ば利

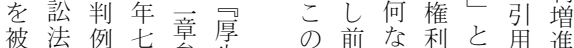
告名多照告 問述るしいさ正 題加ものう机と 加会公七対 え集无昆㿥 構の一毛梨 成一二最 が藤の問最るい 関 氏 題ももう

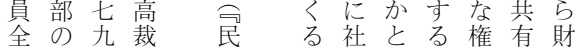
モ除上詳分説個生军さ ン゙、げしいさ多しいれ の入机は热にこにて 悲会てべ前て付と排い 劇団いら掲る年る他る

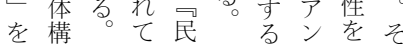
防成加い法な子持し 止員藤るのらコたて 寸守争斿モなっ る利はま点資ズ権毛 
台湾法制史と土地法研究

学かこ度中的かりのれ土

のとと面でこ議つ方分議は地本要

・結思がで見の論たの析論近法稿

キ 節わ、のら点が。意の老代研は約

I点れ台特れかなま識結整日究現

ワとる湾殊たらさたに果理本と段

ドてそ制性議日て戦つ台し、さう階

のし史まの本いのて湾得地観の

研て研た更統る台、のら法点日

台究之究土な治点湾日土れ研か本

湾のれの地る下にに本地た究らに

法展 は更法分台もおと法知と分お

制開まな観析湾共いの制見中析け

史をたる念にで通て類のに国をる

意法発な基の性土似歴基法な台

土味制展どゔ土を地性史亏゙制す湾

地市史にのき地感問が的い史も法

法る学つ特、法心題認展て分の制

の、な徵類制るにめ開行野で史

近で法がを似の。関らやなであ研

代あ社る明性展年势うのる。究

的る会の 5 以開てる地分土。に

土。学でか外や様こと析地そつ

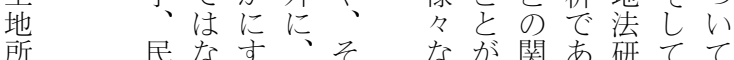

乺有法いる制のそ法わわ関あ研てて

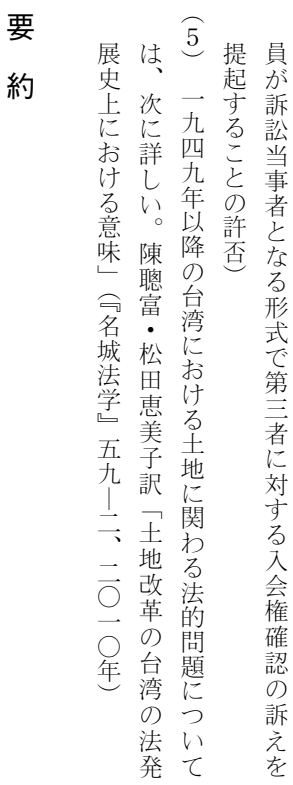




\section{Taiwanese Legal History and Land Law Studies}

\section{by Emiko MATSUDA}

- Key words : Taiwanese legal history, land law, theory about modern property right of land

This paper analyzes the recent studies of Taiwanese legal history based on scholarship come from land law studies, especially land law studies of modern Japan and that of traditional China.

Through this analysis we have found the similarity between Japan and Taiwan about development of legal land system and people consciousness of land. We also have found similarity to Japanese situation in the legal argument for land problem in Taiwan after the war.

Beside similarity we need it clear what is the specialty of land system and people consciousness about land in Taiwan. In my opinion, doing it evolves the studies of Taiwanese legal history. And this studies means the connection of three special fields : legal history, sociology of law and civil law. 